\title{
KEBIJAKAN KRIMINAL TERHADAP TINDAK PIDANA POLIGAMI DIKAITKAN DENGAN SISTEM HUKUM PERKAWINAN INDONESIA
}

\author{
Ateng Sudibyo \\ Fakultas Hukum Universitas Majalengka \\ E-mail: atengsudibyo099@gmail.com
}

\begin{abstract}
Law No. 1 of 1974 on Marriage basically adhere to the principle of monogamy. Although not essential to the principle of monogamy, there is still a polygamist who often take shortcuts to legalize polygynous marriage. Polygamous marriage act is a violation of Law No. 1 Year 1974 on Marriage, and Government Regulation No. 9 of 1975 on implementation of Law No. 1 Year 1974 on Marriage, although the threat of criminal sanction only published in the Government Regulation. Another case in the Criminal Code (KUHP), the sanction of polygamy as criminal action regulated in Article 279. Is the threat of criminal sanctions contained in the Criminal Code and Regulation No. 9 of 1975 in line with the values and ideals of community law in Indonesia? The purpose of this study is to determine the applicative policy for polygamy as criminal offense in marriages in Indonesia's legal system and to formulate the concept of criminalisation policy for polygamous marriage act as criminal offense in the Indonesia's legal system of marriage for the future. This is due to criminal sanctions in Article 279 of the Criminal Code and Law No. 1 of 1974 and Article 45 of Government Regulation Number 9 Year 1975, there is still a legal synchrony. The concept of future criminal polygamy criminal policies should apply the principle of ultimum remedium otherwise known as the "last drug". Whatever the reason for the imposition of criminal punishment will still have a negative effect on the perpetrator and his family and will cause sociological and psychological implications if criminal sanctions are applied. In the legal state of Pancasila especially for the Muslims, the concept of marriage is a worship then it must be fostered, if there are deviations should not be destroyed by a criminal threat. Therefore, to overcome the criminal act of polygamy the need of a non penal criminal policy means, that is prevention without punishment.
\end{abstract}

\section{Kata Kunci: Kebijakan Kriminal, Sanksi Pidana, Tindak Pidana Poligami}

\section{A. Latar Belakang}

Perkawinan merupakan peristiwa penting dalam kehidupan manusia, terutama bagi masyarakat Indonesia karena tidak saja menyangkut pribadi kedua calon suami isteri tetapi menyangkut urusan keluarga dan masyarakat. Lembaga 
perkawinan dengan berbagai bentuknya telah ada sepanjang sejarah peradaban manusia, baik dalam bentuk eksogami, endogami, monogami maupun poligami. (Tengku Erwinsyahbana, 2012: 1). Melalui lembaga perkawinan jumlah manusia di muka bumi akan semakin bertambah, karena keturunan manusia tidak akan berlanjut tanpa adanya perkawinan. Perkawinan menyebabkan adanya keturunan dan melalui keturunan tercipta keluarga yang berkembang menjadi masyarakat, sedangkan masyarakat dapat diartikan sebagai bentuk kehidupan bersama yang di dalamnya terdapat individu dan/atau kelompok sebagai anggotanya yang saling mengadakan interaksi untuk kelangsungan hidupnya.

Kesejahteraan, ketenteraman dan keserasian hidup dalam masyarakat sangat tergantung kepada kesejahteraan, ketenteraman dan keserasian suatu keluarga sebagai unit terkecil dari masyarakat. Menurut Moh. Zahid (2002: 1), dikatakan bahwa:

Keluarga terbentuk melalui perkawinan, yaitu sebagai ikatan antara dua orang yang berlainan jenis dengan tujuan membentuk keluarga. Ikatan suami isteri yang didasarkan niat suci ini diharapkan tumbuh berkembang menjadi keluarga rumah tangga bahagia kekal berdasarkan Ketuhanan Yang Maha Esa, dan dalam lingkungan keluarga ini pula seorang anak manusia dibesarkan, dididik dan diarahkan agar kelak kemudian hari menjadi manusia dan anggota masyarakat yang beriman, bertakwa, berilmu pengetahuan, berteknologi dan berwawasan nusantara.

Tujuan perkawinan seperti disebut di atas adakalanya sulit diwujudkan, bahkan sering terjadi bahwa walaupun pasangan suami isteri telah berupaya membina kehidupan rumah tangganya dengan sebaik mungkin, tetapi ada saja masalah yang dapat menyebabkan rumah tangga tidak bahagia. Dalam perkawinan juga tidak hanya muncul persoalan perdata saja, terkadang dalam perkawinan juga akan menimbulkan masalah yang menyangkut kepidanaan.

Menyikapi masalah-masalah yang terjadi dalam perkawinan, maka peranan hukum dibutuhkan untuk mengantisipasi dan menyelesaikan masalah yang dapat menyebabkan perselisihan dalam perkawinan (termasuk akibat dari perkawinan itu sendiri) dan tentunya hukum perkawinan yang telah dipositifkan melalui produk peraturan perundang-undangan dan sejak tahun 1974 di Indonesia upaya ini telah dilaksanakan, yakni dengan disahkannya Undang-undang Nomor 1 
Tahun 1974 tentang Perkawinan (UU No. 1 Tahun 1974). Berlakunya UU No. 1 Tahun 1974 diharapkan dapat menyelesaikan berbagai permasalahan yang terkait dengan perkawinan, tetapi faktanya setelah undang-undang ini mulai berlaku, ternyata ditemui hambatan (kendala) dalam tahap aplikasinya, yang salah satu di antaranya adalah terkait dengan masalah poligami yang masih dilakukan tanpa mengukuti prosedur menurut undang-undang

Poligami merupakan permasalahan yang cukup signifikan untuk dianalisis, karena masih menimbulkan kontroversi dalam masyarakat. Ada anggapan bahwa perkawinan poligami merupakan permasalahan klasik yang tidak perlu diperdebatkan, karena jelas persyaratan untuk melakukan poligami dalam undang-undang perkawinan sangatlah ketat, bahkan dalam KUHPerdata yang menganut asas monogami mutlak jelas tidak diperbolehkan adanya perkawinan poligami, tetapi faktanya praktik perkawinan poligami tetap terjadi dan jika hal ini dibiarkan berlanjut, bukan tidak mungkin pada masa akan datang, terjadi persoalan hukum yang sulit untuk diselesaikan, misalnya terhadap status hukum, kedudukan anak, agama, pembagian harta warisan, dan lain-lain.

Poligami di Indonesia diatur dalam UU No. 1 Tahun 1974, Peraturan Pemerintah Nomor 9 Tahun 1975 tentang Pelaksanaan UU No. 1 Tahun 1974 tentang Perkawinan (PP No. 9 Tahun 1975) dan Instruksi Presiden Nomor 1 Tahun 1991 tentang Penyebarluasan Kompilasi Hukum Islam (KHI) yang khusus bagi penganut agama Islam (Mohd. Idris Ramulyo, 1996: 184), dan pada dasarnya asas yang melekat dalam undang-undang perkawinan tersebut merupakan asas monogami, tetapi dalam undang-undang tersebut tidaklah berimplikasi pada asas monogami mutlak, melainkan asas monogami terbuka (M. Yahya Harahap, 1975: 25-26). Sebaliknya asas yang melekat pada KHI adalah asas poligami tertutup, sebab secara tersurat dalam Pasal 55 ayat (1) KHI dijelaskan bahwa asas perkawinannya adalah poligami, tetapi pasal-pasal setelahnya mengindikasikan untuk menutup asas poligami tersebut dengan berbagai persyaratan yang begitu ketat, sehingga tidak memungkinkan bagi para pelaku poligami untuk menerapkannya dengan sewenang-wenang. Pada dua asas tersebut, tentunya terdapat konsekuensi hukum yang sama, yaitu poligami diperbolehkan di Indonesia, tetapi 
kebolehan tersebut hanya dapat berjalan dengan persyaratan yang sangat ketat dan selektif.

Berdasarkan ketentuan-ketentuan yang tercantum dalam UU No. 1 Tahun 1974 dan PP No. 9 Tahun 1975, dapat dirumuskan bahwa seorang suami yang bermaksud untuk beristeri lebih dari seorang (berpoligami), haruslah memenuhi ketentuan-ketentuan sebagaimana yang tercantum di dalam UU No. 1 Tahun 1974 dan PP No. 9 Tahun 1975, tetapi perbuatan yang dapat dikategorikan sebagai tindak pidana pada perkawinan poligami masih terjadi meskipun secara kuantitas kejahatan yang dilakukan oleh pelaku poligami relatif kecil, sedangkan secara kualitas kejahatan yang dilakukan oleh pelaku poligami sangat meresahkan kehidupan dalam berumahtangga, oleh karena itu diperlukan suatu usaha penanggulangan sedini mungkin.

Kasus kejahatan poligami yang umumya terjadi adalah bentuk pemaksaan suami kepada isteri agar membolehkannya menikah lagi, baik melalui pemaksaan secara halus maupun secara kasar. Dinyatakan (pemaksaan secara halus) bahwa apabila suami tidak diperbolehkan menikah lagi, berarti memberi peluang kepada suami untuk berselingkuh, bahkan berzina dengan perempuan lain. Pemaksaan lain, berupa ancaman untuk meninggalkan isteri dan keluarganya dengan cara memutuskan pemberian nafkah, bahkan ada kasus yang sampai melakukan ancaman kekerasan fisik untuk memperoleh persetujuan dari isteri agar diperbolehkan menikah lagi. Kasus lain adalah dalam melalui bentuk pemalsuan surat persetujuan atau pun mencuri cap jempol saat sang isteri sedang tidur. Ini membuktikan, walaupun undang-undang telah mengatur tentang persyaratan poligami tetapi dalam tataran aplikasinya tindak pidana poligami masih terjadi di tengah-tengah masyarakat.

Merujuk kepada UU No. 1 Tahun 1974, tidak memberikan sanksi pidana terhadap pelaku perkawinan poligami, tetapi rumusan ketentuan pidana hanya terdapat di dalam peraturan pelaksananya, yaitu Pasal 45 PP No. 9 Tahun 1975. sedangkan dalam Kitab Undang-undang Hukum Pidana (KUHP) perumusan tentang kejahatan perkawinan diatur dalam Pasal 279. Ketentuan Pasal 45 PP No. 9 Tahun 1975 atas pelanggaran terhadap Pasal 40 PP No. 9 Tahun 1975 dimaksud 
berkaitan dengan ketiadaan izin poligami dari Pengadilan, sehingga perbuatan poligami yang dilakukan secara liar (tanpa izin pengadilan) dapat dikenakan sanksi pidana berupa membayar denda setinggi-tingginya Rp. 7.500,- (tujuh ribu lima ratus rupiah). Dari unsur-unsur pasal dimaksud, dapatlah diketahui bahwa larangan terhadap poligami bukan terletak kepada hukum pernikahannya, tetapi terletak kepada syarat administrasi yang harus terpenuhi terlebih dahulu yang dibuktikan dengan adanya penetapan dari pengadilan. Berbeda halnya dengan ketentuan sanksi pidana atas perbuatan yang diatur di dalam Pasal 279 KUHP, memandang perbuatan poligami ilegal yang telah ditetapkan oleh undang-undang sebagai tindak pidana yang dapat diancam sanksi pidana penjara.

Perbedaan ancaman sanksi pidana dalam memandang perbuatan poligami liar sebagaimana yang diatur di dalam Pasal 45 PP No. 9 Tahun 1975 dengan Pasal 279 KUHP dikarenakan perbedaan norma-norma dalam ikatan perkawinan yang diadopsi ke dalam hukum positif dimaksud. Pasal 45 PP No. 9 Tahun 1975 memandang perbuatan poligami liar hanyalah sebagai perbuatan pelanggaran administratif semata, hukum dasar perkawinan poligami itu sendiri adalah boleh dan sah jika rukun dan syarat nikah sudah terpenuhi. UU No. 1 Tahun 1974 memandang perkawinan sebagai perbuatan untuk melaksanakan ibadah, sedangkan pencatatan perkawinan hanyalah bersifat administratif. Hal ini sesuai dengan pendapat Tengku Erwinsyahbana (2012: 83) yang mengatakan bahwa: "pencatatan perkawinan bukan merupakan syarat sah perkawinan, tetapi hanya sebagai bentuk persyaratan lain untuk mengakui legalitas perkawinan”, dengan demikian ketentuan poligami dipandang sah jika agama dan kepercayaannya itu terpenuhi, dan apabila perbuatan poligami tersebut dilaksanakan tanpa adanya penetapan izin dari pengadilan, maka kepada pelaku poligami yang melanggar hukum dikenakan sanksi kategori pelanggaran.

Sudut pandang hukum tersebut terbentuk didasari norma-norma hukum perkawinan Islam yang diadopsi kedalam UU No. 1 Tahun 1975. Perkawinan dalam konsep UU No. 1 Tahun 1975 tidak hanya dilihat dari segi hubungan keperdataan saja, juga harus memperhatikan segi-segi agama adat istiadat dan motif-motif yang mendorong perkawinan tersebut. UU No. 1 Tahun 1975 tidak 
menganut asas monogami mutlak, artinya seorang suami diperbolehkan beristeri lebih dari satu dengan syarat harus mendapat izin dari pengadilan. Berbeda dengan sudut pandang hukum, jika melihat pelanggaran poligami dari Pasal 279 KUHP. Perbedaan sudut pandang hukum pada Pasal 279 KUHP disebabkan Pasal 279 KUHP memandang perkawinan bukan sebagai pelaksanaan ibadah, melainkan sebagai suatu hubungan perdata sebagaimana dimaksud Pasal 26 KUHPerdata yang menyebutkan bahwa "undang-undang memandang soal perkawinan hanya dalam hubungan-hubungan perdata" (suatu perkawinan adalah sah apabila telah memenuhi syarat-syarat yang telah ditetapkan dalam undang-undang tanpa memperhatikan segi agama, biologis, dan motif-motif yang mendorong perkawinan itu).

Pasal 27 KUHPerdata mengatur azas monogami mutlak, karena dalam kurun waktu yang sama seorang laki-laki hanya diperbolehkan mempunyai seorang isteri. Perkawinan menimbulkan hak keperdataan, baik bagi suami, isteri, anak dan lain-lain. Hak-hak tersebut diatur dalam KUHPerdata. Adanya perkawinan kedua, ketiga dan lain-lain akan merubah hak-hak keperdataan pasangan, yang timbul dari perkawinan sebelumnya, dan jika perkawinan kedua, ketiga, keempat dilakukan secara melawan hukum, maka telah terjadi perubahan hak keperdataan dari pihak-pihak sebelumnya secara melawan hukum pula dan hal ini dapat mengacaukan kepastian hukum mengenai hak-hak keperdataan tersebut. Agar ada kepastian hukum terkait hak-hak keperdataan tersebut, perlu ada aturan pidana, tetapi Pasal 279 KUHP juga tidak menjamin bahwa orang tidak akan melakukan poligami.

Perkembangan atau peningkatan tindak pidana poligami jika dilihat dari hakikat kejahatan, merupakan masalah kemanusiaan dan masalah sosial yang tidak dapat diatasi semata-mata dengan hukum pidana. Kejahatan merupakan suatu fenomena kemasyarakatan yang dinamis, yang selalu tumbuh dan terkait dengan fenomena dan struktur kemasyarakatan lainnya yang sangat kompleks dan berada di luar jangkauan hukum pidana, maka wajarlah hukum pidana mempunyai keterbatasan kemampuan untuk menanggulanginya (Muladi, 1995: 7), seperti halnya yang disampaikan Sudarto sebagaimana dikutip Barda Nawawi Arief 
(2005:44), bahwa: "penggunaan hukum pidana merupakan penanggulangan suatu gejala kurrien am symptom dan bukan suatu penyelesaian dengan menghilangkan sebab-sebabnya". Keterbatasan kemampuan hukum pidana selama ini juga disebabkan oleh sifat/hakikat dan fungsi hukum pidana itu sendiri. Sanksi (hukum) pidana selama ini bukanlah obat (remedium) untuk mengatasi sebabsebab (sumber) penyakit, melainkan sekedar untuk mengatasi gejala/akibat dari penyakit sehingga harus ada upaya lain yang dilakukan untuk menanggulangi kejahatan.

Upaya lain selain hukum pidana yang berusaha menanggulangi kejahatan inilah kemudian dapat dikatakan sebagai upaya non penal, yaitu suatu upaya rasional dalam menanggulangi kejahatan dengan upaya-upaya lain selain hukum pidana (penal), tetapi jika dilihat dari kebijakan/kriminal (kebijakan penanggulangan kejahatan) sebaiknya ditempuh dengan pedekatan/kebijakan integral, baik dengan menggunakan "penal" maupun dengan sarana "non penal" ke arah penekanan atau pengurangan faktor-faktor potensial bagi tumbuh suburnya tindak pidana dan keduanya dalam fungsinya harus berjalan beriringan secara sinergis, saling melengkapi.

Menurut Barda Nawawi Arief (1996: 39), bahwa: "pelaksanaan penggunaan sarana hukum pidana (sarana penal), haruslah merupakan suatu usaha yang dibuat dengan sengaja dan sadar", artinya pilihan dan penetapan hukum pidana sebagai sarana untuk menanggulangi kejahatan harus benar-benar telah memperhitungkan semua faktor yang dapat mendukung berfungsinya atau bekerjanya hukum pidana itu dalam kenyataannya, sehingga diperlukan pendekatan yang fungsional, dan ini pun merupakan pendekatan yang melekat pada setiap kebijakan yang rasional.

Kebijakan non penal (di luar hukum pidana), antara lain dilakukan dengan kebijakan ekonomi, budaya, sosial, agama, pendidikan, teknologi, dan lain-lain. Tujuan utama dari usaha-usaha non penal selain diharapkan mampu memperbaiki kondisi-kondisi sosial tertentu, secara tidak langsung mempunyai pengaruh preventif terhadap kejahatan (Muladi dan Barda Nawawi Arief, 2005: 159). Dilihat dari sudut politik kriminal, keseluruhan kegiatan preventif yang non penal 
sebenarnya mempunyai kedudukan yang sangat strategis, memegang posisi kunci yang sangat penting untuk diintensifkan dan diefektifkan, yang jika dikaitkan dengan masalah (kejahatan) dalam poligami, maka perlu kiranya dilakukan analisis (penelitian) lebih lanjut.

\section{B. Metode Penelitian}

Jenis penelitian ini adalah yuridis normatif, karena kajian dalam penelitian ini adalah kajian ilmu hukum, oleh karena itu harus dikaji dari aspek hukumnya. Penelitian yuridis normatif disebut juga penelitian hukum kepustakaan (Ronny Hanitijo Soemitro, 1988: 11), atau dikategorikan sebagai penelitian yang mengkaji asas-asas dan kaidah-kaidah hukum (Ronny Hanitijo Soemitro 1990: 11-12). Digunakannya penelitian hukum normatif, karena permasalahan pokoknya mengenai tindak pidana poligami dalam sistem hukum perkawinan Indonesia, dan pendekatannya menggunakan pendekatan perundang-undangan (statute approach) yaitu dilakukan dengan menelaah semua undang-undang dan regulasi yang berkaitan dengan tindak pidana poligami.

Penelitian ini bersifat deskriptif analitis, maksudnya karena peneliti berusaha mengetahui dan memaparkan informasi dan data secara faktual dengan cara sistematis dan akurat mengenai tindak pidana poligami. Bersifat analitis karena peneliti akan melakukan analisis terhadap berbagai aspek hukum, baik dari segi peraturan, maupun dari segi pelaksanaannya, guna mengetahui upaya pencegahan terhadap tindak pidana poligami.

Untuk memperoleh data yang relevan dengan permasalahan yang diteliti, maka penelitian ini dilaksanakan dalam 2 (dua) tahap, yaitu: pertama, penelitian kepustakaan dan kedua, studi lapangan. Penelitian kepustakaan dilakukan dalam rangka memperoleh data sekunder, baik yang berupa bahan hukum primer, bahan hukum sekunder, maupun bahan hukum tertier (Soerjono Soekanto dan Sri Mamudji, 2003: 13). Bahan hukum primer adalah bahan hukum yang bersifat autoritatif (mempunyai otoritas), dan bahan-bahan hukum yang mengikat, yakni norma (dasar) atau kaidah dasar dan peraturan-peraturan dasar, seperti UUD 1945, serta peraturan perundang-undangan yang berkaitan dengan tindak pidana 
poligami. Bahan hukum sekunder adalah bahan hukum yang memberikan penjelasan mengenai bahan hukum primer, berupa hasil-hasil penelitian, karangan ilmiah dari kalangan hukum, dan penelitian-penelitian lain yang relevan dengan penelitian ini, sedangkan bahan hukum tertier adalah bahan yang memberikan petunjuk ataupun penjelasan terhadap bahan hukum primer dan bahan hukum sekunder, berupa kamus, ensiklopedia, majalah, surat kabar dan sebagainya yang dipergunakan untuk melengkapi ataupun menunjang data penelitian ini. Selanjutnya studi lapangan dilakukan dalam rangka memperoleh data primer yang menunjang data sekunder, sehingga dari data primer akan diketahui pelaksanaan penanggulangan tindak pidana polgami.

Teknik pengambilan data yang dilakukan adalah dengan menggunakan teknik:

1. Studi kepustakaan, yaitu dengan mempelajari literatur-literatur yang berhubungan dengan objek penelitian.

2. Wawancara (interview), yaitu mengumpulkan data melalui tanya jawab dengan para pihak yang terkait dengan objek penelitian, sedangkan tipe wawancara yang dipergunakan adalah wawancara tidak terpimpin (non directive interview), artinya seluruh wawancara tidak didasarkan pada satu sistem atau daftar pertanyaan yang telah disusun terlebih dahulu

Setelah data sekunder dan primer terkumpul, kemudian diadakan analisis secara yuridis kualitatif, yaitu menganalisis data berupa uraian-uraian yang sistematis tanpa mempergunakan bagan-bagan dan rumus statistik.

\section{Hasil Penelitian dan Anasilis}

\section{Kebijakan aplikatif tindak pidana poligami dalam sistem hukum perkawinan di Indonesia.}

Upaya untuk membentuk hukum perkawinan telah dimulai sejak masa penjajahan Belanda, tetapi hal ini baru terwujud pada tahun 1974 dengan berlakunya UU No. 1 Tahun 1974. Sejak saat ini telah tercipta unifikasi dalam bidang hukum perkawinan (yang selama ini terserak dalam beberapa jenis peraturan), tetapi unifikasi yang dimaksudkan di sini masih bercorak pluralistik, 
karena memang tidak mungkin mengadakan suatu aturan hukum dalam bidang perkawinan yang berlaku umum bagi semua orang. Dalam hal tertentu, ada kaedah-kaedah agama yang perlu dan harus diindahkan oleh setiap orang ketika akan melangsungkan perkawinan, terutama hal-hal yang terkait dengan syarat materil dalam perkawinan (Tengku Erwinsyahbana, 2012: 300).

Keadaan pluralistik dalam bidang hukum perkawinan, terlihat jelas dari ketentuan yang terdapat dalam Pasal 2 ayat (1) UU No. 1 Tahun 1974, sehingga berdasarkan ketentuan ini, kaedah-kaedah yang terdapat dalam ajaran agama merupakan syarat sah (materil) untuk melangsungkan perkawinan, dan oleh sebab itu pula kaedah-kaedah dalam ajaran agama yang terkait dengan masalah perkawinan menjadi aturan hukum positif di Indonesia. Akibat dari ketentuan ini, ada aturan hukum yang harus diindahkan oleh calon pasangan suami isteri yang akan melangsungkan perkawinan, yaitu: (1) aturan hukum agama; dan (2) aturan yang terdapat dalam UU No. 1 Tahun 1974.

UU No. 1 Tahun 1974, lahir sebagai bentuk atau cerminan dari negara hukum yang berdasarkan Pancasila. Sesuai dengan Penjelasan UUD 1945, disebutkan bahwa Indonesia adalah negara hukum, dan negara hukum yang dimaksudkan di sini, harus dibedakan dengan konsep negara hukum lain, karena negara hukum Indonesia mempunyai corak sendiri yang didasarkan pada Pancasila sebagai falsafah hidup bangsa dan dasar negara.

Pancasila sebagai dasar negara memberikan arti bahwa segala sesuatu yang berhubungan dengan kehidupan ketatanegaraan Republik Indonesia harus berdasarkan Pancasila dan peraturan yang berlaku harus bersumber pada Pancasila, karena Pancasila adalah sumber dari segala sumber hukum. Sesuai dengan makna negara hukum yang berdasarkan Pancasila, maka bangsa Indonesia memiliki sifat religius yang tercermin dari rumusan sila Ketuhanan Yang Maha Esa, yang sekaligus memberikan sifat yang khas kepada Negara Indonesia, yaitu bukan merupakan negara sekuler yang memisahkan antara agama dengan negara dan juga bukan merupakan negara agama.

Terkait dengan masalah perkawinan, maka rumusan Ketuhanan Yang Maha Esa yang menunjukkan bahwa negara Indonesia bukan negara sekuler dan 
bukan pula negara agama, terlihat jelas dalam Pasal 1 UU No. 1 Tahun 1974, yang memberikan pengertian bahwa perkawinan ialah ikatan lahir bathin antara seorang pria dengan seorang wanita sebagai suami isteri dengan tujuan membentuk keluarga (rumah tangga) yang bahagia dan kekal berdasarkan Ketuhanan Yang Maha Esa. Pada sisi lain, aturan agama juga tidak diabaikan oleh negara, karena berdasarkan Pasal 2 ayat (1) UU No. 1 Tahun 1974, ditegaskan bahwa perkawinan adalah sah jika dilaksanakan menurut agama dan kepercayaan para pihak yang melangsungkan perkawinan.

Mengingat bahwa perkawinan sangat erat kaitannya dengan agama dan pada sisi lain terdapat berbagai agama di Indonesia, maka perlu ada aturan hukum perkawinan yang dapat diberlakukan bagi semua pemeluk agama, tanpa sematamata didasarkan pada hukum negara. Oleh sebab itu UU No. 1 Tahun 1974 memasukkan unsur agama dalam pengertian perkawinan dan menentukan bahwa sahnya perkawinan adalah berdasarkan agama dan kepercayaan yang dianut. Ketentuan yang memasukkan unsur Ketuhanan Yang Maha Esa dan Agama dalam UU No. 1 Tahun 1974 sebenarnya sebagai upaya untuk mengakomodir nilai-nilai yang diakui dan berkembang dalam masyarakat, sehingga perkawinan tidak lagi dipandang hanya sebagai kepentingan individu dari sisi keperdataan.

Unsur Ketuhanan Yang Maha Esa dalam pengertian perkawinan, sesuai dengan asas yang dianut dalam negara hukum Pancasila bahwa Pancasila merupakan sumber dari segala sumber hukum negara, dan oleh sebab itu setiap aturan hukum positif yang berlaku di Indonesia, haruslah mencerminkan nilainilai luhur dan murni yang terkandung dalam masing-masing Sila Pancasila dan tentunya dituntun oleh Sila Ketuhanan. Hal ini sesuai dengan pendapat Darji Darmodiharjo dan Shidarta (2008: 231), bahwa: "apabila filsafat hukum mengadakan penilaian terhadap hukum (apakah hukum yang ada itu sudah memenuhi rasa keadilan, kepastian hukum, dan kemanfaatan), maka bagi bangsa Indonesia, yang dipergunakan sebagai ukuran, alat penilai, atau batu ujiannya adalah Pancasila sebagai sumber dari segala sumber hukum”. Pancasila yang jika dilihat sebagai cita hukum (rechtsidee) adalah sebagai pemandu, maka pembentukan hukum positif adalah untuk mencapai ide-ide dalam Pancasila, serta dapat 
digunakan untuk menguji hukum positif yang berlaku. Oleh sebab itu, untuk dapat disebut sebagai suatu sistem hukum, maka aturan hukum yang berlaku tetap harus didasarkan pada Pancasila sebagai cita hukum bangsa Indonesia. Ada sebagian pihak beranggapan bahwa urusan agama dan termasuk di dalamnya terkait dengan masalah perkawinan tidak perlu dicampuri oleh negara. Menurut penulis pendapat ini merupakan pernyataan yang keliru, karena pada satu sisi Indonesia bukan negara sekuler dan pada sisi lain perlu adanya ketertiban dalam masyarakat.

Selanjutnya jika dihubungkan dengan pendapat H.L.A. Hart sebagaimana dikutip R. Otje Salman dan Anton F. Susanto (2005: 90-92), maka dalam hukum perkawinan tentunya harus memuat aspek internal dan aspek eksternal. Aspek internal yang dimaksudkan di sini terkait dengan kewajiban masyarakat untuk mentaati setiap aturan hukum perkawinan yang telah dipositifkan pemerintah, sedangkan aspek ekternal terkait dengan perubahan perilaku masyarakat dalam memandang soal perkawinan.

Harus diakui bahwa dalam aplikasinya masih terdapat ketidakpatuhan masyarakat terhadap aturan hukum perkawinan yang berlaku, sehingga kepastian hukum dalam bidang perkawinan belum sepenuhnya dapat terwujudkan. Hal ini tidak berarti bahwa hukum perkawinan yang ada belum dapat dikatakan sebagai suatu sistem hukum. Ketidakpatuhan (ketidaktaatan) sebagian anggota masyarakat terhadap aturan hukum perkawinan ini terutama mengenai perkawinan poligami, sebenarnya hanya merupakan penyimpangan perilaku sebagian terkecil anggota masyarakat, tetapi secara umum, terjadi perubahan perilaku dalam memandang soal perkawinan. Oleh sebab itu, salah satu tujuan yang ingin dicapai dengan mencantumkan ketentuan pidana bagi pelaku poligami adalah agar terciptanya kepastian hukum dalam perkawinan dan kepastian bagi perempuan dan anak-anak yang lahir dari perkawinan tersebut.

Ketentuan sanksi pidana poligami diatur dalam PP No. 9 Tahun 1975 dan tidak diatur dalam UU No. 1 Tahun 1974 akan menimbulkan ketidakpastian hukum, karena peraturan pemerintah tidak dapat mencantumkan sanksi pidana, jika undang-undang induknya tidak mencantumkan sanksi pidana. Reinhold Zippelius sebagaimana dikutip Budiono (1990: 153-154), mengatakan bahwa: 
"kepastian hukum dapat dibedakan dalam dua pengertian, yaitu: (1) kepastian dalam pelaksanaan, maksudnya bahwa hukum yang resmi diundangkan dilaksanakan dengan pasti oleh negara; dan (2) kepastian orientasi, maksudnya bahwa hukum itu harus jelas, sehingga masyarakat dan hakim dapat berpedoman padanya".

Ketiadaan aturan mengenai sanksi pidana bagi pelaku poligami dalam UU No. 1 Tahun 1974, jelas menyebabkan terjadinya ketidakpastian orientasi hukum, padahal kepastian orientasi berarti hukum itu harus jelas, sehingga masyarakat dan hakim dapat berpedoman padanya. Setiap istilah dalam hukum harus dirumuskan dengan terang dan tegas sehingga tidak ada keragu-raguan tentang tindakan apa yang dimaksud. Begitu pula aturan-aturan hukum harus dirumuskan dengan ketat dan sempit agar keputusan dalam perkara pengadilan tidak dapat menurut tafsiran subyektif dan selera pribadi hakim. Kepastian orientasi menuntut agar ada prosedur pembuatan dan peresmian hukum yang jelas dan dapat diketahui umum. Kepastian orientasi ini juga menuntut agar hukum dikembangkan secara kontinu dan taat asas. Undang-undang harus saling kait mengkait, harus menunjuk ke satu arah agar masyarakat dapat membuat rencana ke masa depan, begitu pula jangan dibuat undang-undang yang saling bertentangan. PP No. 9 Tahun 1975 mengatur tentang sanksi pidana, sedangkan UU No. 1 Tahun 1974 sebagai induk dari PP No. 9 Tahun 1975 tidak mengatur tentang sanksi pidana, menunjukan bukti bahwa politik hukum perkawinan di Indonesia belum memenuhi kriteria atau belum sesuai dengan tujuan negara hukum, karena dalam perspektif negara hukum pada umumnya, maka negara bertujuan untuk menjamin terwujudnya kepastian hukum dalam masyarakat.

Terkait dengan poligami yang seolah-olah dianggap sebagai sebuah kejahatan, maka secara kriminologis dapat dikatakan bahwa poligami tersebut haruslah sebuah perbuatan yang meresahkan masyarakat, dan jika masyarakat Indonesia menganggap poligami adalah meresahkan masyarakat, maka sudah selayaknya hal ini dianggap sebagai sebuah kejahatan. Pemidanaan bagi pelaku poligami juga harus mempertimbangkan tujuan dan target yang akan dicapai, tanpa mempersoalkan seberapa banyak kerugian yang ditimbulkan oleh tindak 
pidana poligami tersebut, dan seberapa hebat dampak yang terjadi sebagai akibat dari perbuatan poligami juga harus menjadi pertimbangan.

Melihat fenomena masyarakat sekarang, rasanya belum saatnya poligami dijadikan sebuah kejahatan. Pertimbangan-pertimbangan yang harus dipenuhi oleh sebuah proses kriminalisasi belum terpenuhi dengan tepat. Kriteria pelaku yang dipidana dalam poligami juga harus diperjelas. Apakah suami saja atau suami dan isteri. Apabila isteri juga dianggap pelaku yang dapat dipidana karena melakukan nikah siri, maka tentu bertentangan dengan tujuan awal yang ingin melindungi perempuan dari ketidakpastian hukum dalam pernikahan poligami tersebut.

Masalah poligami berkaitan dengan masalah hukum administrasi, ancaman penjara atau sanksi pidana rasanya terlalu berlebihan bila diberlakukan bagi pelaku poligami. Sebagaimana diketahui hukum pidana adalah the last resort atau upaya terakhir yang dilakukan bila upaya lain sudah tidak bisa dilakukan. Apalagi melihat dampak spiritual yang mungkin akan terjadi. Kepercayaan suatu agama yang membolehkan pernikahan poligami, tetapi kemudian dianggap kejahatan oleh hukum negara, dan jika hal ini terjadi, maka diyakini akan memberikan hasil yang tidak baik.

Hukum negara tidak boleh bertentangan dengan hukum suatu agama, tetapi proses pengkriminalisasian di atas tentu berkaitan dengan politik hukum suatu negara, sehingga jika dikaitkan dengan hukum positif, maka secara umum dapat dikatakan bahwa politik hukum adalah kebijakan yang diambil (ditempuh) oleh negara (melalui lembaganya atau pejabatnya) untuk menetapkan hukum yang mana yang perlu diganti, atau yang perlu diubah, atau hukum yang mana yang perlu dipertahankan, atau hukum mengenai apa yang perlu diatur atau dikeluarkan agar dengan kebijakan penyelenggaraan negara dan pemerintahan dapat berlangsung dengan baik dan tertib agar tujuan negara (seperti menyejahterakan rakyat) secara bertahap dan terencana dapat terwujud (Bintan Regen Saragih, 2006: 17).

Pembuat peraturan baru/kriminalisasi pada unsur-unsur tindak pidana poligami, menunjukkan adanya pengaturan secara rinci tentang perbuatanperbuatan yang dilarang. Ada beberapa peraturan atau undang-undang yang 
merupakan dasar hukum dalam menentukan akibat hukum dari poligami, antara lain:

a. Pasal 3, 4 dan 5 UU No. 1 Tahun 1974;

b. Pasal 40, 41, 42, 43,44 dan 45 PP No. 9 Tahun 1975;

c. Pasal 279 KUHP, bahwa perbuatan poligami ilegal diancaman hukum penjara maksimal 5 (lima) tahun;

d. Pasal 4, 5, 6, 7, 8, 9, 10 dan 11 Peraturan Pemerintah Nomor 10 Tahun 1983 tentang Izin Perkawinan dan Perceraian Pegawai Negeri Sipil;

e. Peraturan Pemerintah Nomor 45 Tahun 1990 tentang Perubahan atas Peraturan Pemerintah Nomor 10 Tahun 1983 tentang Izin Perkawinan dan Perceraian Pegawai Negeri Sipil; dan

f. Pasal 55, 56, 57, dan 58 KHI, yang menurut Abd. Rahman (1992: 126), didasarkan pada Al-Qur'an, yaitu Q.S. An-Nisa: 3, yang artinya: “dan jika kamu takut tidak akan berbuat adil terhadap (hak-hak), maka kawinilah wanita-wanita (lain) yang kamu senangi dua,tiga atau empat. kemudian jika kamu takut tidak akan berbuat adil, maka(kawinilah) seorang saja, atau budakbudak yang kamu miliki. Yang demikian itu adalah lebih dekat kepada tidak berbuat aniaya".

Melihat berbagai hukum positif di Indonesia yang mengatur tentang tindak pidana poligami, maka dapatlah diketahui bahwa poligami liar dipandang sebagai tindak pidana, tetapi sanksi pidana yang mengancam tindak pidana poligami dapat berbeda-beda, tergantung dari peraturan yang dijadikan dasarnya. Dalam Pasal 45 PP No. 9 Tahun 1975, perbuatan poligami ilegal diancaman dengan sanksi denda setinggi-tinggi Rp. 7.500.- (tujuh ribu lima ratus rupiah), sedangkan jika dilihat dari Pasal 279 KUHP maka perbuatan poligami ilegal dengan ancaman penjara maksimal 5 (lima) tahun, yang secara substansial, tentu akan menimbulkan ketidakpastian hukum.

Berbicara tentang kepastian hukum, maka hal ini tidak dapat dilihat hanya dari aspek sosiologis, melainkan harus dianalisis secara normatif dengan cara menganalisis suatu produk perundang-undangan, baik dalam hal kesesuaiannya dengan asas-asas hukum yang berlaku umum dan cita hukum yang merupakan 
norma fundamental negara, maupun kesesuaiannya dalam hirarki peraturan perundang-undangan atau sinkronisasi antara peraturan yang satu dengan peraturan lainnya pada tingkat vertikal dan horizontal. Kepastian hukum secara normatif umumnya dilihat dari keberlakukan peraturan yang dibuat dan diundangkan secara pasti karena mengatur secara jelas dan logis. Jelas dalam pengertian tidak menimbulkan keragu-raguan atau multitafsir, dan logis dalam pengertian menjadi suatu sistem norma yang tidak saling berbenturan atau menimbulkan konflik norma.

Ketidaksinkronan antara penentuan sanksi pidana yang termuat dalam PP No. 9 Tahun 1975 dan Pasal 279 KUHP sebagaimana yang diuraikan di atas, mengakibatkan terganggunya sistem peradilan pidana terhadap tindak pidana poligami, antara lain terkait dengan penentuan dasar hukum penentuan penjatuhan sanksi kepada pelaku tindak pidana tersebut. Padahal sistem peradilan pidana adalah sistem dalam suatu masyarakat untuk menanggulangi masalah kejahatan. Menanggulangi berarti suatu usaha untuk mengendalikan kejahatan agar berada dalam batas-batas toleransi masyarakat. Sistem ini dianggap berhasil apabila sebagian dari pelaporan maupun keluhan masyarakat yang menjadi korban kejahatan dapat diselesaikan dengan diajukannya pelaku ke sidang pengadilan dan diputuskan bersalah, serta mendapat sanksi pidana (Henny Nuraeny, 2011: 84).

Mencermati UU No. 1 Tahun 1974 sebagai induk dari PP No. 9 Tahun 1975 yang tidak dimuat sanksi pidana, tetapi sebaliknya PP No. 9 Tahun 1974 memuat sanksi pidana, maka hal ini merupakan penyimpangan, karena dalam peraturan pemerintah tidak boleh menyimpang dari materi yang diatur dalam undang-undang yang bersangkutan, sehingga Pasal 45 PP No. 9 Tahun 1975 seharusnya dapat dinyatakan batal demi hukum. Begitu pula, ketentuan Pasal 279 KUHP memandang perbuatan poligami ilegal yang telah ditetapkan oleh undangundang sebagai tindak pidana kategori kejahatan ringan (rechtsdeliktern) yang dapat diancam sanksi pidana, tetapi Indonesia sebagai negara hukum menganut beberapa asas peraturan perundang-undangan, salah satunya adalah asas lex specialis derogat legi generalis yang mengandung makna bahwa aturan hukum yang khusus (lex specialis) mengenyampingkan aturan hukum yang umum (lex 
generalis). PP No. 9 Tahun 1975 sebagai kesatuan yang tidak terpisahkan dari UU No. 1 Tahun 1974 adalah aturan khusus yang mengatur segala sesuatu yang berkenaan dengan perkawinan termasuk ketentuan pidana yang terdapat di dalamnya sehingga memiliki kekuatan untuk mengeyampingkan ketentuan pidana berkenaan dengan perkawinan yang termuat dalam KUHP (Yusrizal, Hamid Sarong, Iman Jauhari, 2016: 27). Apabila Pasal 279 KUHP tetap diterapkan untuk menjerat tindak pidana poligami tentu akan bertentangan dengan nilai-nilai yang hidup dalam masyarakat dan akan menyebabkan hukum menjadi tidak pasti.

Untuk menjamin adanya keteraturan (kepastian hukum) dan ketertiban diupayakan penegakan hukum pidana yang integral, karena hukum pidana tidak akan mampu menjadi satu-satunya sarana dalam upaya penanggulangan kejahatan yang begitu kompleks yang terjadi di masyarakat. Mengingat adanya keterbatasan kemampuan hukum pidana, maka untuk mengatasi tindak pidana poligami perlu ditempuh dengan kebijakan kriminal (criminal policy) yang menggunakan pendekatan penal dan non penal. Masalah utama adalah mengintegrasikan dan mengharmonisasikan kegiatan atau kebijakan non penal dan penal itu sendiri ke arah penekanan atau pengurangan faktor-faktor potensial bagi tumbuh suburnya tindak pidana. Kebijakan penal dilakukan dengan menggunakan hukum pidana, sedangkan kebijakan non penal (di luar hukum pidana), yang antara lain dilakukan dengan kebijakan ekonomi, budaya, sosial, agama, pendidikan, teknologi, dan lain-lain. Berdasarkan uraian di atas, maka perlu dilakukan penanggulangan terhadap tindak pidana poligami, yaitu dengan menggunakan sarana penal dan non penal (kebijakan kriminal).

Bertitik tolak dari paparan di atas meskipun pemerintah telah mengeluarkan peraturan yang terkait dengan sanksi pidana poligami yang terdapat dalam Pasal 45 PP No. 9 Tahun 1975 dan Pasal 279 KUHP, tetapi dalam tataran aplikasinya peraturan tersebut belum efektif diterapkan, dikarenakan tindak pidana poligami di masyarakat yang masih terjadi. Hal ini terjadi karena dalam tataran formulasinya kurang tepat, misalnya jika ditinjau dari segi yuridis ancaman sanksi pidana yang terdapat dalam Pasal 45 PP No. 9 Tahun 1975, tidak dimuat dalam UU No. 1 Tahun 1974 dan ancaman yang terdapat dalam Pasal 279 
KUHP merupakan kejahatan, sedangkan perkawinan poligami merupakan permasalahan administrasi, sehingga akan mempengaruhi ketataran berikutnya yaitu tahap tahap aplikasi (kebijakan yudikatif) dan tahap eksekusi (kebijakan administratif). Ditinjau dari segi sosiologis, masalah perkawinan itu, merupakan permasalahan kepercayaan orang dengan orang, yaitu laki-laki dengan perempuan dan tidak ada permasalahan sepanjang suka sama suka, begitu pula dengan aspek budaya juga mendukung bahwa poligami itu bukan merupakan kejahatan yang harus dikenakan hukuman pidana dan kalaupun tindak pidana poligami ditegakkan dengan memberikan sanksi pidana kepada pelakunya, justru akan lebih banyak mudharatnya dari pada manfaatnya. Apabila seorang suami dipenjara karena melakukan poligami yang tidak memenuhi prosedur, akan mengakibatkan kerugian bagi keluarga yang ditinggalkannya terutama dalam hal mencari nafkah untuk anak dan isterinya.

\section{Konsep kebijakan kriminal tindak pidana poligami dalam sistem hukum perkawinan di Indonesia masa yang akan datang.}

Upaya untuk menuju ke arah unifikasi hukum, terutama terhadap bidang kehidupan yang bersifat sensitif termasuk hukum perkawinan merupakan hal yang sangat sulit untuk diwujudkan, karena dihadapkan pada kendala berupa kemajemukan masyarakat yang memiliki keanekaragaman agama, suku dan budaya. Unifikasi hukum yang ingin dilakukan harus tetap memperhatikan dan menampung kemajemukan yang ada pada masyarakat Indonesia dan salah satu unifikasi hukum yang diharapkan adalah dalam bidang hukum perkawinan, walaupun upaya ini telah dimulai dengan memberlakukan UU No. 1 Tahun 1974, tetapi tetap tidak dapat menghilangkan keadaan pluralisme hukum.

Pluralisme hukum memang tidak mungkin dapat dihindari, karena dalam faktanya pada masyarakat Indonesia terdapat berbagai agama yang mempunyai aturan hukum sendiri dalam bidang hukum perkawinan dan pada masing-masing kelompok masyarakat terdapat pula aturan hukum tidak tertulis yang dikenal dengan istilah hukum adat yang juga ada mengatur bidang hukum perkawinan. Oleh sebab itu, upaya unifikasi hukum dalam bidang hukum perkawinan ini tidak dapat terhindar dari keadaan pluralisme hukum. Mengingat adanya pluralisme ini, 
maka tepat kiranya dalam Pasal 2 ayat (1) UU No. 1 Tahun 1974 ditentukan bahwa sahnya perkawinan jika dilangsungkan menurut agama atau kepercayaan dari calon pasangan suami isteri yang akan melangsungkan perkawinan.

Perbedaan ancaman sanksi pidana dalam memandang tindak pidana poligami sebagaimana yang diatur di dalam Pasal 45 PP No. 9 Tahun 1975 dengan Pasal 279 KUHP dikarenakan perbedaan norma-norma dalam ikatan perkawinan yang diadopsi kedalam hukum positif dimaksud. Pasal 45 PP No. 9 Tahun 1975 memandang tindak pidana poligami hanyalah sebagai perbuatan pelanggaran administratif keperdataan semata, hukum dasar perkawinan poligami itu sendiri adalah boleh dan sah jika rukun dan syarat nikah sudah terpenuhi. Dalam penjelasan Pasal 2 ayat (1), disebutkan bahwa tidak ada perkawinan di luar hukum masing-masing agama dan kepercayaannya itu. Ini berarti bahwa dalam bidang perkawinan, hukum agama, termasuk hukum Islam telah mendapat kekuatan yuridis dan materiil. Dikaitkan dengan teori Negara Hukum Pancasila, hal tersebut sesuai dengan maksud Pasal 29 ayat (2) UUD 1945 di mana digariskan bahwa negara menjamin kemerdekaan tiap-tiap penduduk untuk memeluk agamanya masing-masing dan untuk beribadat menurut agama dan kepercayaannya itu. Yang dimaksud dengan hukum masing-masing agamanya dan kepercayaannya itu termasuk ketentuan perundang-undangan yang berlaku bagi golongan agama dan kepercayaannya itu sepanjang tidak bertentangan atau tidak ditentukan lain dalam undang-undang ini.

Dilihat dari teori kepastian hukum yang terdapat dalam UU No. 1 Tahun 1974 memandang perkawinan sebagai perbuatan untuk melaksanakan ibadah, sedangkan pencatatan perkawinan hanyalah bersifat administratif keperdataan dan ketentuan poligami dipandang sah selama ketentuan agama dan kepercayaannya itu terpenuhi dan apabila tindak pidana poligami tersebut dilaksanakan tanpa adanya penetapan izin dari pengadilan, maka sanksi yang diberikan kepada pelaku poligami yang melanggar ketentuan tersebut dikenakan sanksi kategori pelanggaran administratif dan hendaknya adalah sanksi administratif, bukan sanksi pidana sehingga tidak tepat jika diancam dengan hukuman penjara. Memidanakan pelaku poligami merupakan langkah yang berani di tengah masyarakat yang 
menganut agama Islam, kalau pelaku poligami diancam dengan pidana maka dampaknya akan muncul di tengah masyarakat tentang adanya perselingkuhan dan hubungan seksual secara bebas (tanpa ikatan perkawinan).

Ancaman sanksi pidana dalam tindak pidana poligami yang terdapat dalam Pasal 279 KUHP, jika dikaitkan dengan pendapat Lawrence M. Friedman (1977: 6-7), yang menyatakan bahwa:

Hukum itu sebagai suatu sistem yang terdiri dari tiga komponen, pertama, legal substance (aturan-aturan dan norma-norma); kedua, legal structure (institusi atau penegak hukum seperti polisi, jaksa, hakim, dan pengacara), dan ketiga, legal culture (budaya hukum yang meliputi agama atau kepercayaan, ide-ide, sikap, dan pandangan tentang hukum).

Ancaman sanksi pidana dalam Pasal 279 KUHP bertentangan dengan budaya hukum yang meliputi agama atau kepercayaan. Dalam agama Islam tidak ada sanksi pidana bagi pelaku poligami, dikarenakan poligami itu sifatnya mubah artinya diperbolehkan tetapi tidak dianjurkan. Hal ini akan menimbulkan ketidakpastian hukum.

Semestinya hukum harus memberikan jaminan bagi terciptanya kepastian hukum yang didukung oleh tiga hal yang saling terintegrasi satu sama lainnya, yaitu substansi hukum (legal subtance), struktur hukum (legal structur) dan budaya hukum (legal culture). Salah satu unsur saja tidak bisa terpenuhi, kepastian hukum akan menjadi sebuah wacana dan mimpi di siang bolong dan untuk mewujudkan kepastian hukum pada sebuah negara yang berlandaskan hukum, harus didukung dengan keberadaan peraturan perundang-undangan yang memadai dan mengakomodir semua permasalahan dalam bidang hukum, inilah yang dimaksudkan oleh Friedman sebagai substansi hukum (Lawrence M. Friedman 1977: 6-7 dan Satya Arinanto, 2006: 11).

Munculnya gagasan kriminalisasi terhadap perkawinan poligami didasari anggapan adanya perbuatan yang merugikan orang lain (yaitu perempuan dan anak) atau masyarakat akibat perkawinan ilegal tersebut, tetapi kalau poligami ditolak dengan dalih ingin melindungi kaum wanita dan anak-anak, kenapa tidak mengurus masalah prostitusi dan kumpul kebo yang juga merugikan wanita dan anak-anak, yang juga jelas melecehkan kaum wanita, dan kalau mau berdalih 
poligami membuka peluang wanita untuk ditinggalkan begitu saja oleh laki-laki, apakah yang nikah resmi dan dicatatkan ke KUA tidak ada yang ditinggalkan begitu saja oleh suaminya tanpa keterangan dan merugikan anak isteri, hal ini tentu tergantung moral dan niat laki-laki itu sendiri.

Persyaratan poligami sebagaimana diatur oleh UU No. 1 Tahun 1974 sudah baik, tetapi sulit sekali dilaksanakan, sehingga banyak terjadi pelanggaran. Semestinya pembuat undang-undang dapat meninjaunya kembali, agar di satu sisi poligami tidak ditutup rapat, tetapi di lain pihak pelaku poligami dapat berbuat adil. Bagaimanapun poligami tidak dapat dianggap ilegal apalagi di kriminalisasi, karena manfaatnya juga banyak, selain sisi negatifnya yang harus diminimalisasi sekecil mungkin (Ahmad Barjie, http://tulisanbarjie.blogspot.co.id).

Masalah kriminalisasi poligami haruslah sesuai dengan kebijakan kriminal yang dianut oleh bangsa Indonesia, yaitu sejauh mana perbuatan tersebut bertentangan atau tidak bertentangan dengan nilai-nilai fundamental yang berlaku dalam masyarakat dan oleh masyarakat dianggap patut atau tidak patut dihukum dalam rangka menyelenggarakan kesejahteraan masyarakat. Kriminalisasi terhadap poligami patut untuk dikaji dengan prinsip kehati-hatian. Bagaimana akibatnya jika suatu perbuatan dijadikan sebagai tindak pidana, sedangkan masyarakat menilai perbuatan tersebut sebagai perbuatan yang patut atau tidak tercela. Pelaku poligami harus didekriminalisasi atau didepenalisasi. Pencantuman sanksi pidana bagi pelaku tindak pidana poligami menunjukkan pemerintah melakukan tindakan seperti membunuh tikus dalam lumbung padi, sebab akan timbul pertanyaan kenapa pemerintah tidak menjalankan opsi non penal (di luar hukum pidana) dalam mengatur tindak pidana poligami (Edi Setiadi. http://artikel media.blogspot.co.id)

Mengingat kebijakan non penal lebih bersifat tindakan pencegahan untuk terjadinya (poligami) sasaran utamanya adalah menangani faktor-faktor kondusif penyebab terjadinya tindak pidana poligami tersebut. Faktor kondusif tersebut antara lain berpusat pada masalah-masalah atau kondisi-kondisi sosial yang secara langsung atau tidak langsung dapat menimbulkan atau menumbuhsuburkan tindak pidana poligami. Dengan demikian, dilihat dari sudut politik kriminal secara 
makro dan global, upaya non penal menduduki posisi kunci dan strategis dari keseluruhan upaya politik kriminal.

Konsep kebijakan kriminal tindak pidana poligami masa yang akan datang seharusnya menerapkan asas ultimum remedium atau dikenal dengan "obat terakhir”. Ini diperlukan untuk mempertimbangkan dahulu penggunaan sanksi lain sebelum sanksi pidana dijatuhkan, apabila fungsi hukum lainnya kurang maka baru dipergunakan hukum pidana. Permasalahan tindak pidana poligami sangat berkaitan erat dengan masalah pelanggaran administrasi, sehingga permasalahan administrasi tentang permasalahan poligami harus dikedepankan, menginggat apapun alasannya penjatuhan pidana tetap akan menimbulkan efek negatif bagi pelaku maupun keluarganya dan akan menimbulkan implikasi sosiologis kalau penegakan pidana diterapkan. Di negara Indonesia terutama untuk yang beragama Islam, konsep perkawinan itu merupakan ibadah maka harus dibina, apabila ada penyimpangan jangan dibinasakan dengan adanya ancaman pidana.

\section{Simpulan dan Saran}

\section{Simpulan}

a. Hukum positif yang mengatur tentang tindak pidana poligami, tetapi sanksi pidana yang mengancam tindak pidana poligami berbeda-beda, tergantung dari peraturan yang dijadikan dasarnya. Dalam Pasal 45 PP No. 9 Tahun 1975, perbuatan poligami ilegal diancaman dengan sanksi denda setinggi-tinggi Rp. 7.500.- (tujuh ribu lima ratus rupiah), sedangkan jika dilihat dari Pasal 279 KUHP maka perbuatan poligami ilegal dengan ancaman penjara maksimal 5 (lima) tahun, yang secara substansial, tentu akan menimbulkan ketidakpastian hukum.

b. Permasalahan tindak pidana poligami sangat berkaitan erat dengan masalah pelanggaran administrasi, sehingga permasalahan administrasi tentang permasalahan poligami harus dikedepankan, menginggat apapun alasannya penjatuhan pidana tetap akan menimbulkan efek negatif bagi pelaku maupun keluarganya dan akan menimbulkan implikasi sosiologis kalau penegakan pidana diterapkan. 


\section{Saran}

a. Untuk menjamin adanya keteraturan (kepastian hukum) dan ketertiban diupayakan penegakan hukum pidana yang integral, karena hukum pidana tidak akan mampu menjadi satu-satunya sarana dalam upaya penanggulangan kejahatan yang begitu kompleks yang terjadi di masyarakat, dan untuk mengatasi tindak pidana poligami perlu ditempuh dengan kebijakan kriminal (criminal policy) yang menggunakan pendekatan penal dan non penal.

b. Masalah kriminalisasi poligami haruslah sesuai dengan kebijakan kriminal yang dianut oleh bangsa Indonesia, yaitu sejauh mana perbuatan tersebut bertentangan atau tidak bertentangan dengan nilai-nilai fundamental yang berlaku dalam masyarakat dan oleh masyarakat dianggap patut atau tidak patut dihukum dalam rangka menyelenggarakan kesejahteraan masyarakat. 


\section{DAFTAR PUSTAKA}

\section{Buku/Kamus:}

Abd. Rahman. 1992. Kompilasi Hukum Islam di Indonesia. Jakarta: Akademika Pressindo.

Barda Nawawi Arief. 2005. Beberapa Aspek Kebijakan Penegakan dan Pengembangan Hukum Pidana. Edisi Revisi. Bandung: Citra Aditya Bakti.

- 1996. Kebijakan Legislatif dalam Penanggulangan Kejahatan dengan Pidana Penjara. Semarang: Badan Penerbit Universitas Diponegoro.

--------. 2001. Masalah Penegakan Hukum dan Kebijakan Penanggulangan Kejahatan. Bandung: Citra Aditya Bakti.

Bintan Regen Saragih. 2006. Politik Hukum. Bandung: CV. Utomo.

Budiono Kusumohamidjojo. 1999. Ketertiban yang Adil (Problematik Fisafat Hukum). Grasindo: Jakarta.

Darji Darmodiharjo dan Shidarta. 2008. Pokok-pokok Filsafat Hukum: Apa dan Bagaimana Filsafat Hukum Indonesia. Cetakan Ketujuh. Jakarta: Gramedia Pustaka Utama.

Henny Nuraeny. 2011. Tindak Pidana Perdagangan Orang, Kebijakan Hukum Pidana dan Pencegahannya. Cetakan Kesatu. Jakarta: Sinar Grafika.

Lawrence, M. Friedman. 1977. Law and Society an Introduction. New Jersey: Prentice Hall Inc.

Moh. Zahid. 2002. Dua Puluh Lima Tahun Pelaksanaan Undang-undang Perkawinan. Jakarta: Depertemen Agama R.I.

Muladi dan Barda Nawawi Arief. 2005. Teori-teori dan Kebijakan Pidana. Bandung: Alumni.

Muladi. 1995. Kapita Selekta Sistim Peradilan Pidana. Semarang: Badan Penerbit UNDIP.

Otje Salman, R. dan Anton F. Susanto. 2005. Teori Hukum, (Mengingat, Mengumpulkan dan Membuka Kembali). Cetakan Kedua. Bandung: Refika Aditama.

Ronny Hanitijo Soemitro. 1990. Metodologi Penelitian Hukum dan Jurimetri. Jakarta: Ghalia Indonesia.

Satya Arinanto. 2006. Politik Pembangunan Hukum Nasional dalam Era Pasca Reformasi. Jakarta: Universitas Indonesia.

Soerjono Soekanto dan Sri Mamudji. 2003. Penelitian Hukum Normatif Suatu Tinjauan Singkat. Jakarta: RajaGrafindo Persada. 


\section{Jurnal/Disertasi:}

Tengku Erwinsyahbana. 2012. "Perspektif Hukum Perkawinan Antar Agama yang Berkeadilan Dikaitkan dengan Politik Hukum Perkawinan Indonesia dalam Rangka Pembangunan Hukum Keluarga Nasional”. Disertasi. Bandung: Fakultas Hukum Program Doktor Ilmu Hukum Pascasarjana Universitas Padjadjaran.

Tengku Erwinsyahbana. 2012. "Perspektif Hukum Perkawinan Antar Agama yang Berkeadilan Dikaitkan dengan Politik Hukum Perkawinan Indonesia dalam Rangka Pembangunan Hukum Keluarga Nasional”. Indonesian Journal of Dialectics (IJAD). Vol. 2. No. 2. Agustus. Bandung: Unpad Press.

Yusrizal, Hamid Sarong, dan Iman Jauhari. 2016. "Penggunaan Instrumen Hukum Poligami di Lingkungan Peradilan Umum dan Kaitannya dengan Asas Monogami Peraturan Pemerintah Nomor 9 Tahun 1975". Jurnal Ilmu Hukum. Vol. 4. No. 2. Mei. Banda Aceh: Pascasarjana Universitas Syiah Kuala.

\section{Internet:}

Ahmad Barjie. "Kriminalisasi Poligami dan Nikah Siri". http://tulisanbarjie. blogspot.co.id/2010/12. Diakses tanggal 20 November 2016.

Edi Setiadi. “Opsi Non Penal Nikah Siri”.http://artikelmedia.blogspot.co.id/2010/ 02. Diakses tanggal 26 November 2016. 


\section{BIODATA PENULIS}

$\begin{array}{ll}\text { Nama } & : \text { Dr. Ateng Sudibyo, S.H., M.H } \\ \text { Pekerjaan } & : \text { Dosen Fakultas Hukum Universitas Majalengka } \\ \text { Jabatan } & : \text { Asisten Ahli } \\ \text { Nomor HP } & : 082319627233 \\ \text { E-mail } & : \text { atengsudibyo099@gmail.com }\end{array}$

Alamat Kantor : Jl. K.H. Abdul Halim No. 103 Majalengka Kulon, Kecamatan Majalengka, Kabaputen Majalengka, Jawa Barat-45418 